\title{
Some Effects of Calcium on the Activation of Human Factor VIII/Von Willebrand Factor Protein by Thrombin
}

\author{
Mary Ellen Switzer and PATrick A. MCKeE, Departments of Medicine \\ and Biochemistry, Duke University Medical Center, \\ Durham, North Carolina 27710
}

\begin{abstract}
A B S T RACT When Factor VIII/von Willebrand factor (FVIII/vWF) protein is rechromatographed on $4 \%$ agarose in $0.25 \mathrm{M} \mathrm{CaCl}_{2}$, the protein and $\mathrm{vWF}$ activity appear in the void volume, but most of the FVIII procoagulant activity elutes later. Recent evidence suggests that the delayed FVIII procoagulant activity is a proteolytically modified form of FVIII/vWF protein that filters anomalously from agarose in $0.25 \mathrm{M} \mathrm{CaCl}_{2}$. To test whether or not thrombin is the protease involved, the effect of $0.25 \mathrm{M} \mathrm{CaCl}_{2}$ on FVIII/vWF and its reaction with thrombin was examined. About $30 \%$ of the FVIII procoagulant activity was lost immediately when solutions of FVIII/vWF protein were made $0.25 \mathrm{M}$ in $\mathrm{CaCl}_{2}$. When FVIII in $0.15 \mathrm{M} \mathrm{NaCl}$ was activated with $0.04 \mathrm{U}$ thrombin $/ \mathrm{ml}$ and then made $0.25 \mathrm{M}$ in $\mathrm{CaCl}_{2}$, the procoagulant activity of a broad range of FVIII/vWF protein concentrations remained activated for at least $6 \mathrm{~h}$. But, in $0.25 \mathrm{M} \mathrm{CaCl}_{2}$, the increase in FVIII procoagulant activity in response to thrombin was much more gradual and once activated, the procoagulant activity was stabilized by $0.25 \mathrm{M} \mathrm{CaCl}_{2}$. When thrombin-activated FVIII/vWF protein was filtered on $4 \%$ agarose in $0.15 \mathrm{M} \mathrm{NaCl}$, there was considerable inactivation of FVIII procoagulant activity; however, the procoagulant activity that did remain eluted in the void volume. In contrast, when thrombin-activated FVIII/vWF protein was filtered in $0.25 \mathrm{M}$ $\mathrm{CaCl}_{2}$, the FVIII procoagulant activity eluted well after the void volume and remained activated for $6 \mathrm{~h}$. The procoagulant peak isolated by filtering nonthrombin-activated FVIII/vWF protein on agarose in $0.25 \mathrm{M}$ $\mathrm{CaCl}_{2}$ was compared to that isolated from thrombinactivated FVIII/vWF protein. Both procoagulant ac-
\end{abstract}

This work was presented, in part, at the Annual Meetings of the American Society for Clinical Investigation, Atlantic City N. J., May 1975 and the Federation of American Societies for Experimental Biology, Anaheim, Calif., April 1976.

Dr. Switzer is presently a National Institutes of Health Postdoctoral Fellow.

Received for publication 9 February 1977 and in revised form 6 May 1977. tivity peak proteins had about the same specific $\mathrm{vWF}$ activity as the corresponding void volume protein. Before reduction, the sodium dodecyl sulfate gel patterns for the two procoagulant activity peak proteins were the same. After reduction, the gel pattern for the nonthrombin-activated procoagulant activity peak protein contained bands of $195,000,148,000-120,000$, $79,000,61,000,51,000$, and 18,000 daltons whereas the pattern for the reduced thrombin-activated procoagulant activity peak protein always lacked the higher molecular weight bands, but consistently showed the four lower molecular weight bands to be well resolved. Taken together, these results imply that thrombin generates the FVIII procoagulant activity that is stabilized by $0.25 \mathrm{M} \mathrm{CaCl}_{2}$ and elutes aberrantly from $4 \%$ agarose in that solvent.

\section{INTRODUCTION}

The initial physicochemical characterization of a purified protein with Factor VIII (FVIII) ${ }^{1}$ procoagulant activity appeared to establish that it is a glycoprotein with a mol wt $>1$ million daltons and a covalent subunit structure (1-9). Subsequently it was shown that this glycoprotein also had von Willebrand factor (vWF) activity and it was suggested that the two activities (i.e. FVIII and vWF) might be properties of the same molecule and conceivably of each subunit (10-12). More recently it has been shown that when the FVIII/vWF protein(s) is rechromatographed on $4 \%$ agarose in certain high ionic strength solvents, particularly $0.25 \mathrm{M} \mathrm{CaCl}_{2}$, virtually all of the protein and $\mathrm{VWF}$ activity elute in the void volume, but most of the FVIII procoagulant activity elutes much later (1321). These observations have led to the development, explicitly or implicitly, of four different hypotheses for the structure-function relationships of the FVIII/vWF

\footnotetext{
${ }^{1}$ Abbreviations used in this paper: FVIII, Factor VIII; SDS, sodium dodecyl sulfate; TAMe, $p$-toluenesulfonylL-arginine methylester; vWF, von Willebrand Factor.
} 
protein: (a) The FVIII procoagulant activity is associated with a small subunit noncovalently bound to a large "carrier" subunit. This model would imply a definite stoichiometry between the carrier protein and the small, active subunit. (b) The two activities are associated with two different proteins that form a complex. Depending on binding constants, the FVIII procoagulant and $\mathrm{VWF}$ proteins might be expected to have several favorable combining ratios, but the stoichiometric requirements of this model would be less rigid than for the first. (c) The FVIII procoagulant and vWF activities are associated with two different proteins that simply co-purify. This model would impose no stoichiometric restrictions on the combining ratios of these two unrelated proteins. $(d)$ The FVIII procoagulant and $\mathrm{vWF}$ activities are properties of a single molecule composed of disulfide-bound identical subunit polypeptide chains. In this model, the action of thrombin or thrombin-like enzymes on the molecule gives rise to a derivative which has FVIII procoagulant activity and which elutes later from $4 \%$ agarose in $0.25 \mathrm{M} \mathrm{CaCl}_{2}$.

Recent evidence from this laboratory was interpreted to support the last model $(22,23)$. This conclusion was based on our demonstration that the FVIII procoagulant activity appeared larger than 400,000 daltons by Sephadex G-200 chromatography in $0.25 \mathrm{M}$ $\mathrm{CaCl}_{2}$ and by sodium dodecyl sulfate (SDS) polyacrylamide-gel electrophoresis. Also the quantities of protein associated with the two activities were incompatible with a reasonable stoichiometry, and the FVIII procoagulant activity protein also had vWF activity. The presence of $\mathrm{vWF}$ activity in the FVIII procoagulant activity peak and the SDS-gel pattern for the reduced FVIII procoagulant activity peak protein suggested that this protein is a proteolytically modified FVIII/vWF species that interacts with agarose in $0.25 \mathrm{M} \mathrm{CaCl}_{2}$ and thereby elutes anomalously. This report presents additional studies of the effects of calcium on the activities of the FVIII/vWF protein(s) as well as on its gel filtration and electrophoretic behavior before and after exposure to thrombin.

\section{METHODS}

Reagents. Reagent-grade chemicals were used without further purification. Unless otherwise noted, all solutions were buffered to $\mathrm{pH} 7.35$ with $0.05 \mathrm{M}$ Tris hydrochloride (Tris).

Protein concentrations. These were measured by the absorbance at $280 \mathrm{~nm}$, corrected for light scattering, and expressed as absorbance units.

FVIII procoagulant activity assays. FVIII procoagulant activity was measured by the kaolin-activated partial thromboplastin time method using hemophilic plasma with $<1 \%$ FVIII activity as the substrate (8). The modifications required to measure FVIII procoagulant activity in the presence of $0.25 \mathrm{M} \mathrm{CaCl}_{2}$ have been described in detail (23); in short, one must both dilute the test sample and change the order of reagent addition. More specifically, the FVIII solution was diluted to $0.043 \mathrm{M} \mathrm{CaCl}$ and added to a $37^{\circ} \mathrm{C}$ mixture of $0.1 \mathrm{ml}$ of $0.05 \mathrm{M}$ Tris- $0.15 \mathrm{M} \mathrm{NaCl}, 0.1 \mathrm{ml}$ of Thrombofax (Ortho Diagnostics, Inc., Raritan N. J.) and $0.1 \mathrm{ml}$ of hemophilic substrate plasma; the time required to form a visible clot was then recorded. The FVIII procoagulant activity in units per milliliter was computed from a standard curve obtained by assaying one of the National Institute of Health $(\mathrm{NIH})$ reference plasmas $(0.76$ or $1.2 \mathrm{U} / \mathrm{ml})$ in $0.043 \mathrm{M}$ $\mathrm{CaCl}_{2}$, using the same order of reagent addition. With these modifications, the clotting time for each dilution of reference plasma was longer and the slope of the standard curve of clotting time vs. log percent dilution was steeper than the slope obtained when the assay was performed using the regular order of reagent additions.

Thrombin assays. The esterase activity of thrombin was measured by determining the rate of hydrolysis of $p$ toluenesulfonyl-L-arginine methyl ester (TAMe) by the method of Walsh (24). The change in absorbance at $247 \mathrm{~nm}$ for the hydrolysis of $1 \mu \mathrm{mol}$ of TAMe was taken to be 0.409 $(1 / \mathrm{cm}) \cdot(1 / \mathrm{mM})(24)$.

The proteases activity of thrombin was measured by the rate of hydrolysis of the synthetic peptide S-2160, $N$-benzoylL-phenylalanyl-L-valyl-L-arginine- $p$-nitroanilide hydrochloride (AB Bofors, Molndal, Sweden), by the method of Blomback et al. (25). The substrate was dissolved in deionized water to a concentration of $\sim 0.65 \mathrm{mg} / \mathrm{ml}$. A volume of 0.15 $\mathrm{ml}$ or less of the test sample was mixed with $1.0 \mathrm{ml}$ of 0.025 M Tris- $0.025 \mathrm{M}$ imidazole- $0.15 \mathrm{M} \mathrm{NaCl}-0.02 \%$ sodium azide buffer, $\mathrm{pH} 8.2$, at $37^{\circ} \mathrm{C}$; then $0.125 \mathrm{ml}$ of substrate also $37^{\circ} \mathrm{C}$ was added. The incubation mixtures were left at $37^{\circ} \mathrm{C}$ for $5 \mathrm{~min}$ at which time the reaction was stopped by adding $0.15 \mathrm{ml}$ of glacial acetic acid. The absorbance at $400 \mathrm{~nm}$, which is proportional to the concentration of $p$-nitroaniline released, was then determined and expressed as a function of the thrombin concentration. The assays were performed in test tubes that had been soaked overnight in a $0.1 \%$ solution of bovine serum albumin (Sigma Chemical Co., St. Louis, Mo.) in deionized water; this procedure was more effective than silicone coating in preventing the loss of thrombin by adsorption to the test tube wall.

Purification of FVIII/vWF protein(s). The starting material for the purification of FVIII/vWF was either the intermediate or high purity concentrate as prepared by the American National Red Cross Laboratory, Bethesda Md., (courtesy of Dr. M. Wickerhauser and Dr. Y. L. Hao) (26). The intermediate-purity FVIII/vWF was converted to high purity FVIII/vWF by dissolving in $0.2 \mathrm{M} \epsilon$-aminocaproic acid to about $18 \mathrm{mg}$ protein $/ \mathrm{ml}$, adsorbing for $10 \mathrm{~min}$ with $10 \mathrm{mg}$ of bentonite (Sigma Chemical Co.,)/ml and then precipitating the protein twice with polyethylene glycol (Carbowax 4,000, Union Carbide Corp., New York) as previously described (23). The final precipitate was washed four times with icecold $8 \%$ ethanol in $0.05 \mathrm{M}$ Tris- $0.15 \mathrm{M} \mathrm{NaCl}$ buffer; subsequently the precipitate was dissolved in $0.05 \mathrm{M}$ Tris- 0.15 $\mathrm{M} \mathrm{NaCl}$ at about $20 \mathrm{mg}$ protein/ml and chromatographed as described in a later section. The FVIII/vWF concentrates supplied in the high purity form were not subjected to the bentonite adsorption step, but instead were simply dissolved in $0.2 \mathrm{M} \epsilon$-aminocaproic acid and chromatographed.

The high-purity FVIII/vWF solutions were further purified by gel filtration at room temperature on a $4 \times 38-\mathrm{cm}$ column of $4 \%$ agarose in $0.05 \mathrm{M}$ Tris- $0.15 \mathrm{M} \mathrm{NaCl}, \mathrm{pH} 7.35$, (Biogel A15m, Bio-Rad Laboratories, Richmond Calif.) as previously described (23). The volume of the FVIII/vWF sample applied to the column was about $25 \mathrm{ml}$, the flow rate $\sim 15 \mathrm{ml} / \mathrm{h}$ and the fraction vol $\sim 7 \mathrm{ml}$. The void volume fractions were pooled on the basis of their content of FVIII 
procoagulant or vWF activity; the protein was precipitated by adding one-third volume $40 \%$ polyethylene glycol at $4^{\circ} \mathrm{C}$. The FVIII/vWF precipitate was collected by centrifugation at $6,000 \mathrm{~g}$ and $4^{\circ} \mathrm{C}$, redissolved in $0.05 \mathrm{M}$ Tris- $0.15 \mathrm{M} \mathrm{NaCl}$ buffer to a concentration of at least 3 absorbance $\mathrm{U} / \mathrm{ml}$ and stored at $-20^{\circ} \mathrm{C}$ in $0.1-1-\mathrm{ml}$ aliquots in plastic tubes. Our yield was about $35 \%$ relative to the starting concentrate and the product was stable for up to 9 mo at $-20^{\circ} \mathrm{C}$. The ultra-high purity FVIII/vWF prepared by this method was homogeneous by SDS gel electrophoresis before and after reduction and gave a single immunoprecipitin line when it was diffused or electrophoresed against unadsorbed rabbit antiserum (23). The ultra-high purity FVIII/vWF protein had about 25 FVIII U/absorbance U; however, the level of vWF units was found to vary depending on the methods used to relate unitage to that of whole plasma. Although the construction of a ratio of FVIII activity to $\mathrm{vWF}$ activity might seem useful, particularly since it should equal unity, it probably is not a reliable index of the purity of FVIII/vWF protein. There are several reasons why it is difficult to relate these two activities back to normal plasma; $(a)$ the exact concentration of the FVIII/vWF protein(s) in normal plasma is not known; $(b)$ trace proteases quickly destroy FVIII activity but leave most of the vWF activity intact; $(c)$ only about $25 \%$ of the FVIII activity in normal plasma is recovered by the majority of purification procedures; $(d)$ other plasma proteins may have differential effects on either of the two activities; and $(e)$ the results of assays measuring the two activities of highly purified FVIII/ vWF may not be exactly comparable to those of assays conducted in whole plasma. Hence the VWF activity of our purified FVIII/vWF material is defined essentially the same as previously (23).

Enhancement of FVIII procoagulant activity by thrombin. The purified human thrombin used for these experiments was supplied as a lyophilized powder (568 NIH U/absorbance $\mathrm{U}$ at $280 \mathrm{~nm}$; courtesy of Dr. D. L. Aronson, Bureau of Biologics, FDA, Bethesda, Md.). The thrombin was reconstituted in $0.05 \mathrm{M}$ Tris- $0.15 \mathrm{M} \mathrm{NaCl}$ and stored at a concentration of $200 \mathrm{NIH} \mathrm{U} / \mathrm{ml}$ at $4^{\circ}$ or $-20^{\circ} \mathrm{C}$. Just before use, the stock solution of thrombin was diluted in polystyrene test tubes which had been previously equilibrated with a thrombin solution as recommended by other investigators (27). Factor VIII was activated by adding 4-10 $\mu$ l of the desired thrombin dilution per $\mathrm{ml}$ of highly purified FVIII/vWF. The reaction mixture was incubated at room temperature in a plastic tube which was gently tilted for the 1st min to insure adequate mixing. FVIII procoagulant activity in the incubation mixture was then monitored at selected time intervals.

Electrophoresis. Sample preparation and SDS-polyacrylamide gel electrophoresis were done as described by Weber and Osborn (28) with slight modifications as reported from our laboratory (8). Staining, destaining, and gel storage were done as described earlier (8).

Chromatographic studies. Ultra-high purity FVIII/vWF protein was rechromatographed on $4 \%$ agarose columns in the solvent systems indicated in Results; a constant flow rate was maintained for each column by the use of a peristaltic pump at the column outlet. Plastic chromatographic columns with agarose bed dimensions of $0.9 \times 11$ and $0.9 \times 26 \mathrm{~cm}$ were used in these experiments. In each experiment a sample volume of $\sim 0.5 \mathrm{ml}$ was applied directly to the top of the agarose. Flow rates of 4 and $6 \mathrm{ml} / \mathrm{h}$ and fraction volumes of 0.45 and $0.6 \mathrm{ml}$ were used for the 11- and $26-\mathrm{cm}$ columns, respectively. If the columns were to be run in $0.25 \mathrm{M} \mathrm{CaCl}_{2}$, solid $\mathrm{CaCl}_{2}$ was added to the FVIII/vWF sample just before chromatography. Fractions to be pooled for SDS-gel electro- phoresis were dialyzed overnight at $4^{\circ} \mathrm{C}$ against 2,000 times their vol of distilled water, quick-frozen, lyophilized, and stored at $-20^{\circ} \mathrm{C}$ for future SDS-gel electrophoretic studies. To remove as much residual calcium as possible, samples which contained $\mathrm{CaCl}_{2}$ were routinely dialyzed overnight against 2,000 vol of distilled water containing a fourfold molar excess of EDTA and then dialyzed twice for 2-3 h each time against $2,000 \mathrm{vol}$ of distilled water to remove the EDTA.

Platelet studies. The ristocetin-induced aggregation of washed human platelets was measured with a ChronoLog aggregometer (Chrono-Log Corp., Havertown, Pa.) (23). To compute vWF activity, the maximum slope of percent transmittance vs. time was determined and taken as the initial velocity $(v)$ of platelet aggregation. A standard curve of $1 / v$ vs. 1/FVIII/vWF (as determined from the absorbance at $280 \mathrm{~nm}$ ) was constructed for dilutions of ultra-high purity FVIII/vWF in $0.15 \mathrm{M} \mathrm{NaCl}-0.05 \mathrm{M}$ Tris. The reciprocal of the concentration of purified native FVIII/vWF required to produce the $1 / v$ value of the test sample was then determined from the standard curve and taken as an estimate of the vWF activity in the test sample.

\section{RESULTS}

Effect of calcium chloride on FVIII procoagulant activity. To examine the effect of $0.25 \mathrm{M} \mathrm{CaCl}_{2}$ on procoagulant activity before thrombin activation, 20 different samples of FVIII/vWF at different concentrations of protein were divided into two sets; one set was left in $0.15 \mathrm{M} \mathrm{NaCl}-0.05 \mathrm{M}$ Tris and the other set was adjusted to $0.25 \mathrm{M} \mathrm{CaCl}_{2}-0.05 \mathrm{M}$ Tris with solid $\mathrm{CaCl}_{2}$. Each sample in the two sets was adjusted to $0.043 \mathrm{M} \mathrm{CaCl}_{2}$ (23) just before it was assayed at three dilutions by the modified method for solutions containing calcium. Fig. 1 shows that the samples ex-

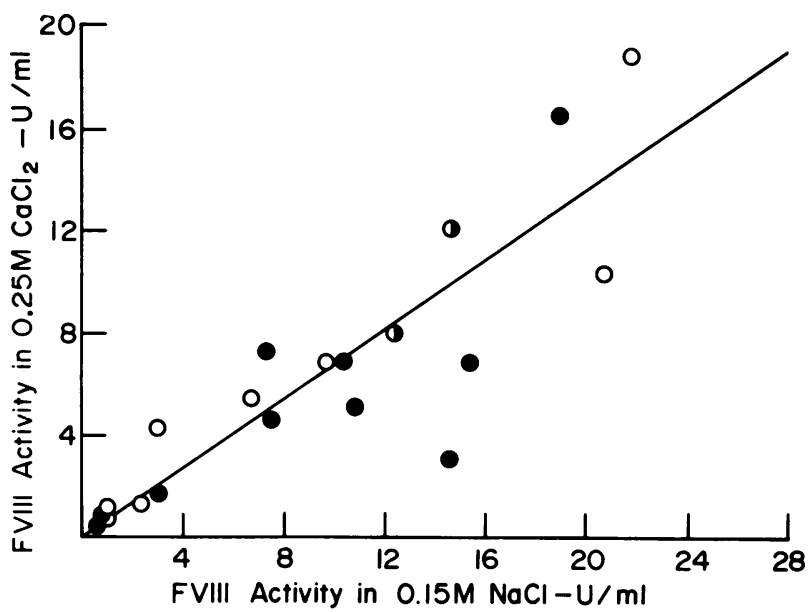

FIGURE 1 A comparison of the FVIII procoagulant activity of the FVIII/vWF protein in $0.25 \mathrm{M} \mathrm{CaCl}_{2}$ vs. $0.15 \mathrm{M} \mathrm{NaCl}$. The solid and open circles correspond to samples assayed at 15 min and $24 \mathrm{~h}$, respectively, after the addition of $0.25 \mathrm{M}$ $\mathrm{CaCl}_{2}$. The slope of this line indicates that the samples in $0.25 \mathrm{M} \mathrm{CaCl}_{2}$ were $\sim 30 \%$ less active than those in $0.15 \mathrm{M}$ $\mathrm{NaCl}$. This loss of FVIII procoagulant activity occurred immediately and no additional losses were observed. 
posed to $0.25 \mathrm{M} \mathrm{CaCl}_{2}$ had only $\sim 70 \%$ of the FVIII procoagulant activity of the corresponding samples in $0.15 \mathrm{M} \mathrm{NaCl}$; greater inactivation seemed to occur at low concentrations of the FVIII/vWF protein. It should be noted that the loss of procoagulant activity occurred immediately upon the addition of $0.25 \mathrm{M} \mathrm{CaCl}_{2}$ and further inactivation could not be detected during the next $24 \mathrm{~h}$.

To test the effect of $0.25 \mathrm{M} \mathrm{CaCl}_{2}$ on thrombin-activated FVIII, six concentrations of FVIII/vWF protein ranging from 0.2 to 5.0 absorbance $U$ were each incubated with a final thrombin concentration of 0.04 $\mathrm{NIH} \mathrm{U/ml} \mathrm{and} \mathrm{assayed} \mathrm{for} \mathrm{FVIII} \mathrm{procoagulant} \mathrm{ac-}$ tivity with time. Again, all samples were adjusted to $0.043 \mathrm{M} \mathrm{CaCl}_{2}$ just before they were assayed for procoagulant activity. In Fig. 2, the mean result of six separate experiments confirmed that in $0.15 \mathrm{M}$ $\mathrm{NaCl}$, thrombin rapidly enhanced FVIII procoagulant activity which then gradually fell to an average of $\sim 40 \%$ of the control level by $6 \mathrm{~h}$. However, when the FVIII/ vWF-thrombin reaction mixture was adjusted to 0.25 $\mathrm{M} \mathrm{CaCl}{ }_{2}$ at $\sim 10 \mathrm{~min}$ after activation had occurred, an immediate $25 \%$ loss of FVIII procoagulant activity was observed; the procoagulant activity then declined to about $140 \%$ of the control value over the next hour and remained essentially at this level for the next 6 h. These results demonstrate that $0.25 \mathrm{M} \mathrm{CaCl}_{2}$ has a

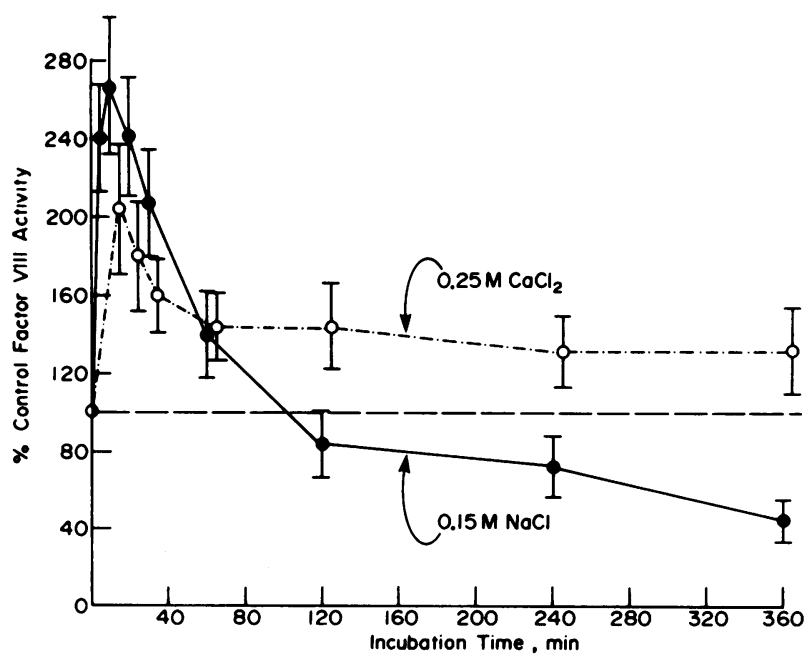

Figure 2 The effect of adding calcium to thrombin-activated FVIII/vWF protein. Each curve shows the mean $\pm \mathrm{SE}$ of six experiments. In $0.15 \mathrm{M} \mathrm{NaCl}$, FVIII procoagulant activity was rapidly activated by a final thrombin concentration of $0.04 \mathrm{NIH} \mathrm{U/ml} \mathrm{and} \mathrm{then} \mathrm{gradually} \mathrm{inactivated}$ below control levels. If the samples were made $0.25 \mathrm{M}$ $\mathrm{CaCl}_{2}$ at maximal activation in $0.15 \mathrm{M} \mathrm{NaCl}$, an immediate $25 \%$ loss of FVIII procoagulant activity occurred. After $1 \mathrm{~h}$, the activity declined to about $160-150 \%$ of the control value and remained at this partially activated level for the next $5 \mathrm{~h}$. stabilizing effect on the procoagulant activity of the FVIII/vWF protein.

Effect of calcium on the thrombin-FVIII/vWF interaction. Solutions of FVIII/vWF protein were prepared in either $0.15 \mathrm{M} \mathrm{NaCl}$ or $0.25 \mathrm{M} \mathrm{CaCl}_{2}$ and adjusted to an absorbance of 1.28 at $280 \mathrm{~nm}$. Thrombin was added to each sample to give a final concentration of $0.04 \mathrm{NIH} \mathrm{U} / \mathrm{ml}$. The effect on procoagulant activity was monitored by removing aliquots from each solution, adjusting to $0.043 \mathrm{M} \mathrm{CaCl}_{2}$ and assaying by the modified method referred to earlier. Fig. 3 shows that in $\mathrm{NaCl}, \mathrm{FVIII}$ procoagulant activity increased to a maximum of $\sim 300 \%$ of the control value in about $10 \mathrm{~min}$. Activity then decreased to control levels by about $2 \mathrm{~h}$ and to substantially inactivated levels after $4 \mathrm{~h}$.

Fig. 3 also shows that in $0.25 \mathrm{M} \mathrm{CaCl}_{2}$, a rapid activation of FVIII procoagulant activity by thrombin did not occur. Instead, there was a gradual increase in activity to $\sim 180 \%$ of control levels by about $2 \mathrm{~h}$ and then a maintenance of this level for another $4 \mathrm{~h}$. These experiments reproducibly demonstrated that $0.25 \mathrm{M}$ $\mathrm{CaCl}_{2}$ inhibited the rapid activation of FVIII procoagulant activity by thrombin. Furthermore, as discussed in the section above, $0.25 \mathrm{M} \mathrm{CaCl}_{2}$ appeared to stabilize FVIII procoagulant activity at a partially activated level.

Effect of EDTA on FVIII/vWF activities. Attempts were made to restore the partial loss of FVIII procoagulant activity that occurred immediately when the FVIII/vWF protein was exposed to $0.25 \mathrm{M} \mathrm{CaCl}_{2}$. Accordingly, samples of FVIII/vWF protein, with and without prior exposure to $0.25 \mathrm{M} \mathrm{CaCl}_{2}$, were dialyzed twice against 100 vol of $0.15 \mathrm{M} \mathrm{NaCl}-0.05 \mathrm{M}$ Tris$0.02 \mathrm{M}$ EDTA for $1 \mathrm{~h}$ each time, and then three times against $0.15 \mathrm{M} \mathrm{NaCl}-0.05 \mathrm{M}$ Tris in the same vol ratio and for the same time periods. Similar to earlier studies using whole plasma (29), the EDTA-treated FVIII/vWF solutions retained $<1 \%$ of the FVIII procoagulant activity of control FVIII/vWF solutions

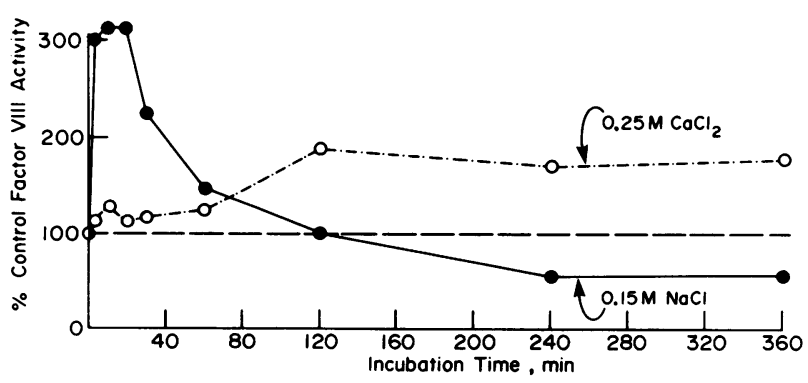

FIGURE 3 Thrombin-activation of FVIII/vWF dissolved in $0.25 \mathrm{M} \mathrm{CaCl}_{2}$ as opposed to $0.15 \mathrm{M} \mathrm{NaCl}$. In $0.25 \mathrm{M} \mathrm{CaCl}_{2}$, FVIII procoagulant activity was activated only very slowly, reaching a peak activity of $\sim 190 \%$ by $2 \mathrm{~h}$. This level of FVIII procoagulant activity was maintained until the experiment was terminated at $6 \mathrm{~h}$. 
which had been dialyzed in an identical manner but never exposed to EDTA. The inactivation of FVIII procoagulant activity was not reversed when the EDTA-exposed FVIII/vWF protein was incubated overnight with calcium or other alkaline earth metals, alkali metals, transition metals, or lanthanides. Dialysis against EDTA had no effect on the vWF activity of FVIII in $\mathrm{NaCl}$.

Effect of calcium on thrombin. To determine whether the decreased rate of activation of FVIII procoagulant activity in $0.25 \mathrm{M} \mathrm{CaCl}_{2}$ was due to an effect on thrombin rather than on FVIII/vWF, the activity of thrombin in $0.25 \mathrm{M} \mathrm{CaCl}_{2}$ was compared to that in $0.15 \mathrm{M} \mathrm{NaCl}$ by three assays: $(a)$ enhancement of FVIII procoagulant activity; (b) TAMe hydrolysis; and (c) proteolysis of a synthetic peptide.

Thrombin dissolved in each of the two solvents was used to activate FVIII/vWF protein concentrations of approximately $0.1,0.5$, and $2.0 \mathrm{mg} / \mathrm{ml}$. Since, as discussed above, FVIII procoagulant activity was enhanced only very slowly when the FVIII/vWF was dissolved in $0.25 \mathrm{M} \mathrm{CaCl}$, these activation experiments were performed using FVIII/vWF dissolved in $0.15 \mathrm{M} \mathrm{NaCl}$. At a final concentration of $0.04 \mathrm{NIH}$ $\mathrm{U} / \mathrm{ml}$, the two thrombin solutions enhanced FVIII procoagulant activity to the same extent and at the same rate. The activation profiles at all three protein concentrations were similar to those shown in Figs. 2 and 3 for activation of FVIII/vWF in $0.15 \mathrm{M} \mathrm{NaCl}$.

The esterase activity of thrombin dissolved in 0.15 $\mathrm{M} \mathrm{NaCl}$ or $0.25 \mathrm{M} \mathrm{CaCl}_{2}$ was examined by the TAMe assay. The rates of hydrolysis for the two solutions of thrombin were essentially the same: 0.193 and 0.189 TAMe U/thrombin NIH U. The two thrombin solutions gave total changes of 0.368 and 0.357 absorbance $\mathrm{U}$ at $247 \mathrm{~nm} / \mathrm{NIH} \mathrm{U}$ of thrombin. These results indicate that $0.25 \mathrm{M} \mathrm{CaCl}_{2}$ has little or no effect on the esterase activity of thrombin.

The proteolytic activity of thrombin dissolved in $\mathbf{0 . 1 5}$ $\mathrm{M} \mathrm{NaCl}$ or $0.25 \mathrm{M} \mathrm{CaCl}_{2}$ was assessed spectrophotometrically by monitoring the amount of $p$-nitroaniline cleaved from the synthetic peptide, $N$-benzoyl-L-phenylalanyl-L-valyl-L-arginyl- $p$-nitroanilide. The absorbance at $400 \mathrm{~nm}$, proportional to the concentration of $p$ nitroaniline released by thrombin proteolysis, was determined after $5-6 \mathrm{~min}$ at $37^{\circ} \mathrm{C}$. Fig. 4 shows the mean results of four such experiments; the percent loss of activity of thrombin in $0.25 \mathrm{M} \mathrm{CaCl}_{2}$ is presented as a function of thrombin concentration. In such analyses $0.25 \mathrm{M} \mathrm{CaCl}_{2}$ had a slight inhibitory effect on the proteolytic activity of thrombin, greatest at low thrombin concentrations, but never more than $\sim 20 \%$. At the thrombin concentration usually used to enhance FVIII procoagulant activity, the proteolytic activity of thrombin in $0.25 \mathrm{M} \mathrm{CaCl}_{2}$ was $\sim 84 \%$ of that for thrombin in $0.15 \mathrm{M} \mathrm{NaCl}$. These three sets of ex-

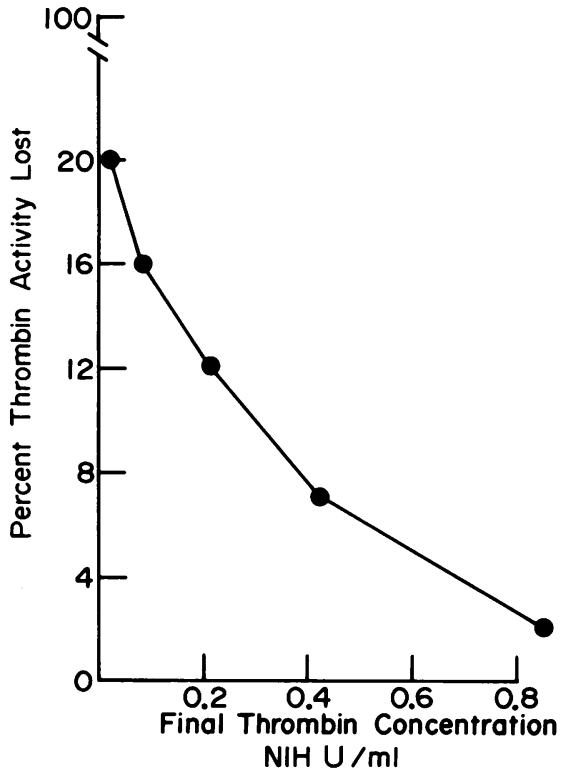

FIGURE 4 The inhibition of the proteolytic activity of different concentrations of thrombin by $0.25 \mathrm{M} \mathrm{CaCl}_{2}$. This effect was measured by comparing the ability of thrombin dissolved in $0.15 \mathrm{M} \mathrm{NaCl}$ vs. $0.25 \mathrm{M} \mathrm{CaCl}_{2}$ to hydrolyze the synthetic peptide $N$-benzoyl-L-phenylalanyl-L-valyl-L-arginyl- $p$ nitroanilide. In this figure the percent loss of thrombin activity in $0.25 \mathrm{M} \mathrm{CaCl}_{2}$ compared to $0.15 \mathrm{M} \mathrm{NaCl}$ is expressed as a function of thrombin concentration. The inhibition of the proteolytic activity of thrombin was maximal $(\sim 20 \%)$ at low thrombin concentrations.

periments indicate that the inhibitory effect of 0.25 $\mathrm{M} \mathrm{CaCl}_{2}$ on the activation of FVIII/vWF by thrombin is mostly a direct effect on the FVIII/vWF protein.

Gel filtration studies on thrombin-activated FVIII/ $v W F$ protein. When thrombin-activated FVIII/vWF was rechromatographed on $4 \%$ agarose in $0.15 \mathrm{M} \mathrm{NaCl}$, the elution profile observed was significantly different from that in $0.25 \mathrm{M} \mathrm{CaCl}_{2}$. These studies were performed by first assaying a sample of FVIII/vWF protein in $0.15 \mathrm{M} \mathrm{NaCl}$ for procoagulant activity, activating one-half of the sample with thrombin for $\sim 10$ min and then simultaneously gel filtering the two samples on identical-sized $4 \%$ agarose columns in $0.15 \mathrm{M}$ $\mathrm{NaCl}$. If the chromatography was to be performed in $0.25 \mathrm{M} \mathrm{CaCl}_{2}$, the appropriate amount of solid calcium chloride was added to the thrombin-activated sample at the peak of activation and at the same time, to the nonthrombin-activated sample. Then, the two samples were each filtered simultaneously in $0.25 \mathrm{M} \mathrm{CaCl}_{2}$ on $4 \%$ agarose columns of the same size. In all of these chromatography experiments the elution fractions from the paired gel filtration analyses of FVIII/ vWF and thrombin-activated FVIII/vWF were assayed immediately for FVIII procoagulant activity. To compare sets of experiments in which different protein concentrations were used, all absorbance or procoagu- 
lant values of a given pair were expressed as a fraction of those of the peak absorbance or procoagulant value, respectively, in the control, nonthrombinactivated, chromatogram.

The protein and FVIII procoagulant activities of control or thrombin-activated FVIII/vWF samples were eluted congruently as sharp peaks in the void volume from $4 \%$ agarose in $0.15 \mathrm{M} \mathrm{NaCl}$ and no other FVIII procoagulant activity was found in later fractions (Fig. $5)$. The mean protein elution patterns were identical in the paired chromatograms. Contrary to our expectations, the FVIII procoagulant activity recovered from the chromatography of thrombin-activated FVIII/vWF was always less than or equal to control levels. Considerable variation in recovery of FVIII procoagu-

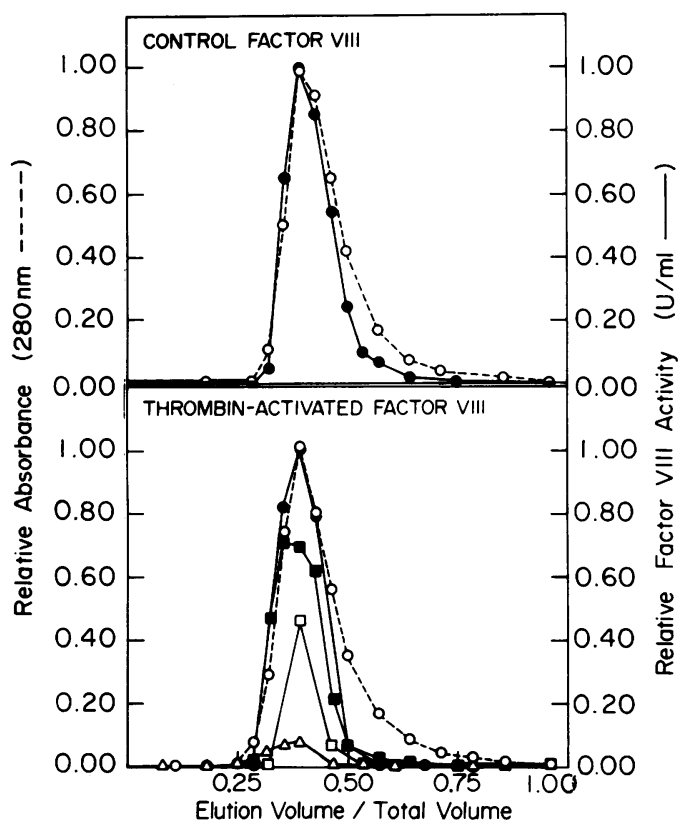

FIGURE $54 \%$ agarose gel filtration of control and thrombinactivated FVIII/vWF protein in $0.15 \mathrm{M} \mathrm{NaCl}$. In both panels the dashed line indicates the absorbance at $280 \mathrm{~nm}$ and the solid lines, using the symbols solid circle, solid square, open square, and open triangle, indicate the FVIII procoagulant activity. To compare several different FVIII/vWF protein concentrations, each experiment in the lower panel is expressed as a fraction of the peak value for its corresponding control chromatogram in the upper panel. The upper panel depicts the mean pattern of four gel filtration experiments with control, nonthrombin-activated FVIII/vWF. The protein and FVIII procoagulant activity were eluted together as sharp peaks in the void volume. The lower panel shows the chromatograms for the four corresponding samples of thrombin-activated FVIII/vWF. Though in each case the FVIII procoagulant activity was increased by thrombin $\sim 3.2$ fold over its control, the FVIII procoagulant activity recovered after chromatography varied from $\sim 10$ to $100 \%$ of the control levels, but never exceeded the control value. Furthermore, in each case, all of the FVIII procoagulant activity was eluted in the void volume. lant activity was seen in the four experiments illustrated. In each experiment, the loss of FVIII activity during chromatography of thrombin-activated FVIII/ VWF was about the same as that of an aliquot of the mixture kept at room temperature for the time required for the chromatography. Such inactivation occurred even when the serine protease inhibitor, $p$-nitrophenylguanidinobenzoate, was added after 10 min to control and thrombin-activated FVIII/vWF solutions at a 10,000-fold molar excess relative to thrombin.

When similar paired experiments were performed in $0.25 \mathrm{M} \mathrm{CaCl}_{2}$, very different results were obtained. Fig. 6 compares the mean chromatogram for 10 agarose gel filtrations of nonthrombin-activated FVIII/vWF to the mean chromatogram for 10 identical experiments with thrombin-activated FVIII/vWF solutions. Both agarose columns were eluted simultaneously in $0.25 \mathrm{M}$ $\mathrm{CaCl}_{2}$ under identical conditions. Shown in Fig. 6, the protein void volume patterns were essentially identical whether or not the FVIII/vWF sample had been exposed to thrombin; however, the void volume FVIII procoagulant activity was much less and the shifted FVIII procoagulant activity peak was substantially larger in the elution pattern for thrombin-activated FVIII/vWF.

When FVIII/vWF or thrombin-activated FVIII/ vWF was rechromatographed on $4 \%$ agarose in $0.25 \mathrm{M}$ $\mathrm{CaCl}_{2}$, the elution profiles of the vWF activity were essentially identical. As indicated in Table I, the specific $\mathrm{vWF}$ activities were about the same in the void volumes and FVIII procoagulant activity peak regions of the two chromatograms. These data clearly show that despite the enhancement of the procoagulant activity peak by thrombin, the vWF activity is not affected. Hence, these results expand previous reports that thrombin has no inhibitory or stimulatory effect on the vWF activity of the FVIII/vWF protein (18, 22 ). It should be noted that only about $35 \%$ of the vWF activity was observed when FVIII/vWF protein dissolved in $0.25 \mathrm{M} \mathrm{CaCl}_{2}$ was added to the ristocetin-platelet aggregation assay as opposed to the same concentration of FVIII/vWF protein in $0.15 \mathrm{M} \mathrm{NaCl}$. Preliminary results suggest that the excess calcium ion primarily suppresses platelet reactivity in the ristocetin assay, although some inhibition may also occur on the FVIII/vWF protein as well.

SDS-gel electrophoretic analyses. Fig. 7 depicts the SDS-7.5\% polyacrylamide gel analyses of fractions from the $0.25 \mathrm{M} \mathrm{CaCl}_{2}-4 \%$ agarose gel filtration of FVIII/vWF and thrombin-activated FVIII/vWF. Nonreduced, the void volume protein recovered from the agarose- $0.25 \mathrm{M} \mathrm{CaCl}_{2}$ filtration of FVIII/vWF or thrombin-activated FVIII/vWF barely penetrated the top of the gel. The reduced SDS-gel pattern for the two void volume samples were also identical, each showing only one subunit band of 195,000 daltons. The SDS- 


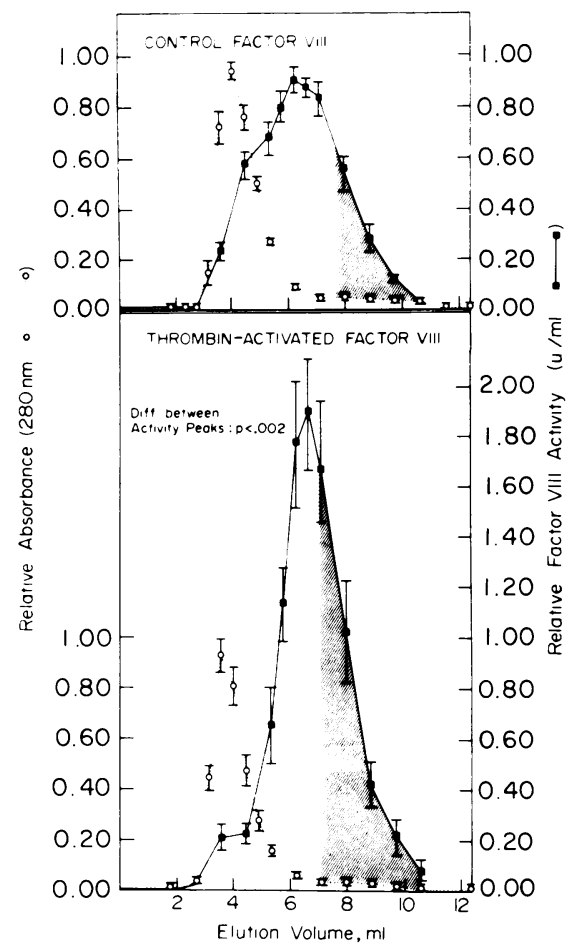

Figure 6 Comparison of the $4 \%$ agarose-0.25 $\mathrm{M} \mathrm{CaCl}_{2}$ filtration patterns of $\mathrm{FVIII} / \mathrm{vWF}$ and thrombin-activated FVIII/vWF (column size: $0.9 \times 11 \mathrm{~cm}$ ). Each panel shows the mean absorbance and the mean FVIII procoagulant activity for 10 sets of experiments. For any given set, one-half of a FVIII/vWF sample was filtered on $4 \%$ agarose in $0.25 \mathrm{M}$ $\mathrm{CaCl}_{2}$ while the other half of the sample was activated by thrombin and filtered simultaneously under the same conditions on an identical-sized column. Absorbance at $280 \mathrm{~nm}$ and FVIII procoagulant activity were expressed as fractions of the peak values, respectively, for the control chromatogram. The fractions in the cross-hatched portion of the descending limb of the FVIII procoagulant peak in each chromatogram were pooled and concentrated for analyses by SDS-gel electrophoresis.

gel patterns for the nonreduced FVIII procoagulant activity peak from either chromatography experiment only showed protein that barely entered the top of the gel, thereby indicating that the FVIII procoagulant activity peak protein is large and does not contain noncovalently bound subunits smaller than $\sim 400,000$ daltons. In the presence of $\beta$-mercaptoethanol, both the control and thrombin-activated FVIII procoagulant activity peak proteins were reduced into several subunits. The FVIII procoagulant activity peak protein separated from FVIII/vFW gave a reduced SDS-gel pattern with major bands of $195,000,79,000,61,000$, 51,000 , and 18,000 daltons and several minor bands, mostly $>100,000$ daltons. The SDS-gel pattern of the reduced FVIII activity peak protein separated from thrombin-activated FVIII/vWF lacked the 195,000-dalton band and the several high molecular weight minor
TABLE I

Relative Specific vWF Activities of Native FVIII/vWF, Thrombin-Activated FVIII/vWF and Pools from $4 \%$ Agarose-0.25 $\mathrm{M} \mathrm{CaCl}_{2}$ Columns

\begin{tabular}{lcc}
\hline & \multicolumn{2}{c}{ Relative vWF activity* } \\
\cline { 2 - 3 } & Native & Thrombin activated \\
\hline $\mathrm{FVIII} / \mathrm{vWF}$ in $\mathrm{CaCl}_{2}$ & 1.00 & 1.00 \\
$\mathrm{CaCl}_{2}$ void volume protein & 0.89 & 0.75 \\
$\mathrm{CaCl}_{2}$ activity peak protein & 0.75 & 0.78 \\
\hline
\end{tabular}

* Mean of three experiments.

bands; the 79,000-, 61,000-, 51,000-, and 18,000-dalton bands were clearly present and well resolved. Similar results were obtained when FVIII/vWF was chromatographed on $4 \%$ agarose in $0.25 \mathrm{M} \mathrm{CaCl}_{2}$ and the separated FVIII procoagulant activity peak then activated by thrombin. These experiments suggest a directed correlation between enhancement of FVIII procoagulant activity, the disappearance of the high molecular weight subunit bands, and the presence of the four lower molecular weight bands in the SDS-gel patterns of the reduced FVIII procoagulant activity peak protein. The presence of the same four bands in the reduced SDS-gel pattern of the FVIII procoagulant activity peak isolated from the nonthrombin-activated FVIII/vWF can be explained by some degree of in vivo or in vitro proteolytic modification by trace thrombin.

\section{DISCUSSION}

The effects of calcium on the FVIII procoagulant activity of FVIII/vWF are complex. After causing an immediate $30 \%$ reduction of the FVIII procoagulant activity, calcium stabilized both native and thrombinactivated FVIII/vWF. This stabilization, coupled with the direct observation that FVIII procoagulant activity was rapidly and irreversibly destroyed when FVIII/ $v W F$ was incubated with $0.02 \mathrm{M}$ EDTA, suggests that the FVIII/vWF molecule contains bound metal ion(s) that hold it in a specific, relatively stable conformation. Removal of the metal ion(s) apparently results in an irreversible conformational change since the addition of calcium or other cations did not restore procoagulant activity.

When thrombin-activated FVIII/vWF was rechromatographed on $4 \%$ agarose in $0.15 \mathrm{M} \mathrm{NaCl}$ or $0.25 \mathrm{M}$ $\mathrm{CaCl}_{2}$, the FVIII procoagulant activity was again stabilized in $\mathrm{CaCl}_{2}$, but not in $\mathrm{NaCl}$. Furthermore, the peak of FVIII procoagulant activity eluted in the void volume with the protein peak in $0.15 \mathrm{M} \mathrm{NaCl}$, but considerably after the void volume in $0.25 \mathrm{M} \mathrm{CaCl}_{2}$. As shown in Fig. 6, comparison of the $4 \%$ agarose- 0.25 $\mathrm{M} \mathrm{CaCl}_{2}$ chromatograms of FVIII/vWF and thrombin- 


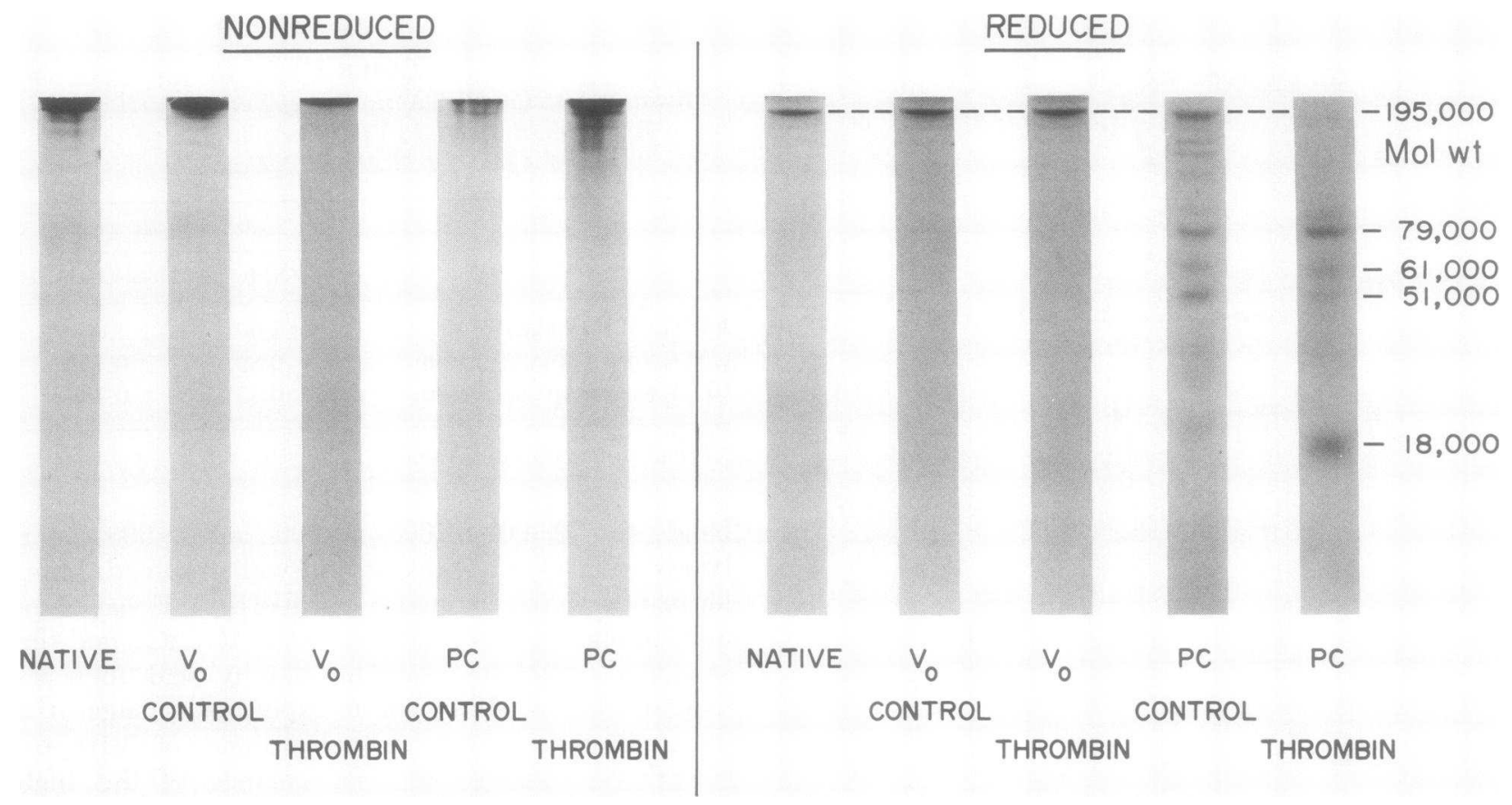

Figure 7 From left to right, the five nonreduced and reduced SDS-7.5\% gel analyses show respectively: purified, native FVIII/vWF; void volume protein from $4 \%$ agarose- $0.25 \mathrm{M}$ $\mathrm{CaCl}_{2}$ filtration of control, nonthrombin-activated FVIII/vWF; void volume protein from the filtration of thrombin-activated FVIII; FVIII procoagulant activity peak protein from $4 \%$ agarose$0.25 \mathrm{M} \mathrm{CaCl}_{2}$ filtration of control FVIII/vWF; and FVIII procoagulant activity peak protein from the filtration of thrombin-activated FVIII/vWF. A comparison of the last two gels shows that the higher molecular weight bands are absent in the pattern of the reduced FVIII procoagulant activity peak protein which had been exposed to thrombin.

activated FVIII/vWF indicates that prior thrombin treatment of the FVIII/vWF protein lessens the amount of FVIII procoagulant activity in the void volume and increases the amount that elutes later. These chromatographic experiments imply that the FVIII procoagulant activity separated by $4 \%$ agarose- $0.25 \mathrm{M} \mathrm{CaCl}_{2}$ chromatography of purified, presumably "native," FVIII/vWF is in fact a very small amount of thrombinactivated FVIII/vWF protein; however, if filtered on $4 \%$ agarose in $0.15 \mathrm{M} \mathrm{NaCl}$, this procoagulant-active species still elutes in the void volume with the major protein peak. This latter finding cannot be reconciled with the report from another group that thrombin promoted the formation of FVIII-procoagulant-active species which eluted well into the inner volume of $4 \%$ agarose in $0.15 \mathrm{M} \mathrm{NaCl}$ (30).

Our SDS-gel analyses of the reduced FVIII procoagulant activity peak protein provide evidence of a change in FVIII/vWF structure resulting from thrombin cleavage. Previous reports which showed that the gel pattern of thrombin-activated FVIII/vWF was identical to that of nonthrombin-activated FVIII/vWF $(7,8)$ could indicate that: $(a)$ no proteolysis had occurred; $(b)$ very minor proteolysis had occurred; or (c) only a small proportion of FVIII/vWF molecules were actually cleaved by thrombin. The results pres- ented in Fig. 7 support the last interpretation since the SDS-gel analyses of the very small amount of protein in the shifted FVIII procoagulant activity peak separated by $4 \%$ agarose- $0.25 \mathrm{M} \mathrm{CaCl}_{2}$ chromatography clearly demonstrated structural differences between the nonthrombin- and thrombin-activated species. In both cases, the nonreduced FVIII procoagulant activity peak protein was too large to penetrate the SDS gels. After reduction of disulfide bonds, several subunit bands were seen in both samples; however, compared to the gel of the reduced FVIII procoagulant activity protein from FVIII/vWF not exposed to thrombin, the gel of the protein from thrombin-activated FVIII/vWF showed a lack of higher molecular weight bands and well-resolved lower molecular weight bands. This pattern suggests that additional thrombin treatment caused more cleavages in a molecule already partially modified by thrombin. A similar reduced SDS-gel pattern was obtained when FVIII procoagulant activity protein was thrombin-activated after separation by $4 \%$ agarose- $0.25 \mathrm{M} \mathrm{CaCl}_{2}$ chromatography of nonthrombin-treated FVIII/vWF.

vWF activity data provide further evidence that the procoagulant activity peak protein is a thrombin-modified form of the void volume protein. The VWF specific activities of the void volume and FVIII procoagu- 
lant activity peak proteins from normal and thrombinactivated FVIII/vWF are essentially identical; thus the observed vWF activity is directly proportional to protein concentration. The presence of $\mathrm{vWF}$ activity in the FVIII procoagulant protein from thrombin-activated FVIII/vWF demonstrates that an intact 195,000 -dalton subunit is not necessary for vWF activity; this result agrees with our report that FVIII/ vWF, which was degraded by plasmin and contained no intact 195,000 -dalton subunits, retained $\sim 70 \%$ of its original $\mathrm{vWF}$ activity (31). The presence of $\mathrm{vWF}$ activity despite the absence of the 195,000-dalton subunit in the FVIII procoagulant protein from thrombinactivated FVIII/vWF also demonstrates that vWF activity is a property of the FVIII procoagulant activity peak protein rather than of protein trailing from the void volume. When considered in toto, these results support and expand our earlier interpretation that the FVIII procoagulant protein is a proteolytically modified FVIII/vWF molecular species (23).

There have been two recent attempts to examine this hypothesis by partially purifying FVIII/vWF in the presence of protease inhibitors and then examining the gel filtration properties of the product $(32,33)$. In the absence of protease inhibitors, Beck et al. (32) found that FVIII procoagulant activity could be separated from vWF activity by $4 \%$ agarose gel filtration in $1.0 \mathrm{M} \mathrm{NaCl}$. But FVIII/vWF prepared in the presence of kallikrein inhibitor (Trasylol, FBA Pharmaceuticals, Inc., New York) could no longer be separated into its component activities when filtered in $1.0 \mathrm{M} \mathrm{NaCl}$ (32). In a similar study, Poon and Ratnoff (33) found that FVIII/vWF prepared in the presence of benzamidine, heparin, soybean trypsin inhibitor, e-aminocaproic acid, and hirudin could still be separated into its component activities on $4 \%$ agarose in $0.25 \mathrm{M} \mathrm{CaCl}_{2}$. The difference between these two studies may reflect differences in the FVIII/vWF preparations, the effectiveness of the inhibitors or the effects of $1.0 \mathrm{M}$ $\mathrm{NaCl}$ and $0.25 \mathrm{M} \mathrm{CaCl}_{2}$. In both of these studies a small amount of activated FVIII/vWF could have been generated before the inhibitors were added, either in vivo or during the venipuncture.

Ultracentrifugation of plasma at high ionic strength has also been reported to produce slow-sedimenting FVIII procoagulant activity (15). It is difficult to draw conclusions about molecular size from such experiments, since FVIII/vWF in whole plasma might exist as a lipoprotein complex. As such, the lipid content might enhance the procoagulant activity of the FVIII/ vWF protein as well as induce flotation effects during centrifugation. This objection was examined by sucrose-gradient experiments on isolated FVIII procoagulant activity peak protein that suggested a low molecular weight for this species (34). Unfortunately the low levels of FVIII activity recovered and the broad peak observed in those experiments make it difficult to estimate molecular weights. But the most serious problem with those studies is the method by which the FVIII procoagulant activity peak was processed before centrifugation. The albumin-stabilized FVIII procoagulant activity peak was "dissociated" from highly purified $\mathrm{FVIII} / \mathrm{vWF}$ by $\mathrm{CaCl}_{2}$-agarose chromatography and then collected into a solution of only partially purified albumin. Since the authors indicate that the albumin contained proteins not precipitated by $50 \%$ saturated ammonium sulfate, there is a good possibility that other clotting factors such as Factor $\mathrm{Xa}$ or lipids might be present among the contaminants and hence might shorten the Factor VIII assay. Furthermore contaminant lipoproteins might bind the FVIII procoagulant protein and give rise to flotation effects to account for an anomalously low molecular weight for the procoagulant activity. Finally, the FVIII procoagulant activity peak protein might possibly interact with sucrose in the same way that it interacts with agarose and thereby sediment aberrantly. The anomalies observed in the $4 \%$ agarose- $0.25 \mathrm{M} \mathrm{CaCl}_{2}$ gel filtration of FVIII/vWF should provide a similar caution for the sucrose-gradient experiments: the proof of molecular weight for the slowly sedimenting activity in sucrose-gradient experiments must await isolation of this species and its characterization by such methods as SDS-gel electrophoresis and or analytical ultracentrifugation in denaturing solvents.

Our results reported here, in conjunction with those of others can be explained by the following model: First, the FVIII/vWF protein present in circulating blood is proposed to be procoagulant-inactive until activated by thrombin. Second, when blood is withdrawn from the circulation, a small amount of thrombin or thrombin-like protease forms as a consequence of the wound or venipuncture and activates some of the FVIII/vWF protein. Third, because FVIII procoagulant activity, but not $\mathrm{vWF}$ activity, is very susceptible to destruction by trypsin-like enzymes such as plasmin, the FVIII/vWF protein must be continuously degraded in vivo such that its procoagulant potential is totally destroyed while virtually all of its $\mathrm{vWF}$ activity remains intact. FVIII/vWF would then be isolated as a mixture of nonactivated precursor FVIII/ vWF, proteolytically inactivated FVIII/vWF and proteolytically activated FVIII/vWF. When the FVIII/ $\mathrm{vWF}$ protein is filtered on $4 \%$ agarose in $0.25 \mathrm{M}$ $\mathrm{CaCl}_{2}$, the large protein peak that elutes in the void volume contains the precursor FVIII/vWF and proteolytically inactivated FVIII/vWF species. The FVIII procoagulant activity protein, resulting from thrombin cleavage of precursor FVIII/vWF, elutes later from $4 \%$ agarose- $0.25 \mathrm{M} \mathrm{CaCl}_{2}$ as a result of interaction with the agarose gel matrix and perhaps self-aggregation. Finally, our data clearly demonstrate that calcium stabilizes the procoagulant activity of the FVIII/vWF molecule. This effect has been essential for the isola- 
tion of FVIII procoagulant protein with an extremely high specific activity and likely will be very important in the recovery of sufficient material for continuing structure function studies on the FVIII procoagulant protein.

\section{ACKNOWLEDGMENTS}

This work was supported by a research grant from the National Heart and Lung Institute, National Institutes of Health (HL 15615).

\section{REFERENCES}

1. Hershgold, E., L. Silverman, A. Davison, and M. Janszen. 1967. Native and purified factor VIII: molecular and electron microscopical properties and a comparison with hemophilic plasma. Fed. Proc. 26: 488. (Äbstr.).

2. Kass, L., O. D. Ratnoff, and M. A. Leon. 1969. Studies on the purification of antihemophilic factor (factor VIII). I. Precipitation of antihemophilic factor by concanavalin A. J. Clin. Invest. 48: 351-358.

3. Ratnoff, O. D., L. Kass, and P. D. Lang. 1969. Studies on the purification of antihemophilic factor (factor VIII). II. Separation of partially purified antihemophilic factor by gel filtration of plasma. J. Clin. Invest. 48: 957-962.

4. Hershgold, E. J., A. M. Davison, and M. E. Janszen. 1971. Isolation and some chemical properties of human factor VIII (antihemophilic factor). J. Lab. Clin. Med. 77: 185-205.

5. Marchesi, S. L., N. R. Shulman, and H. R. Gralnick. 1972. Studies on the purification and characterization of human factor VIII. J. Clin. Invest. 51: 2151-2161.

6. Schmer, G., E. P. Kirby, D. C. Teller, and E. W. Davie. 1972 The isolation and characterization of bovine factor VIII (antihemophilic factor). J. Biol. Chem. 247: 2512-2521.

7. Legaz, M. E., G. Schmer, R. B. Counts, and E. W. Davie. 1973. Isolation and characterization of human factor VIII (antihemophilic factor). J. Biol. Chem. 248: 3946-3955.

8. Shapiro, G. A., J. C. Andersen, S. V. Pizzo, and P. A. McKee. 1973. The subunit structure of normal and hemophilic factor VIII. J. Clin. Invest. 52: 2198-2210.

9. Bennett, B., W. B. Forman, and O. D. Ratnoff. 1973. Studies on the nature of antihemophilic factor (factor VIII). Further evidence relating the AHF-like antigen in normal and hemophilic plasma. J. Clin. Invest. 52: 2191-2197.

10. Bouma, B. N., Y. Wiegerinck, J. J. Sixma, J. A. van Mourik, and I. A. Mochtar. 1972. Immunological characterization of purified anti-hemophilic factor A (factor VIII) which corrects abnormal platelet retention in von Willebrand's disease. Nat. New Biol. 236: 104-106.

11. Weiss, H. J., J.-Regers, and H. Brand. 1973. Defective ristocetin-induced platelet aggregation in von Willebrand's disease and its correction by factor VIII. J. Clin. Invest. 52: 2697-2707.

12. Weiss, H. J., L. W. Hoyer, F. R. Rickles, A. Varma, and J. Rogers. 1973. Quantitative assay of a plasma factor deficient in von Willebrand's disease that is necessary for platelet aggregation: relationship to factor VIII procoagulant activity and antigen content. J. Clin. Invest. 52: 2708-2716.

13. Weiss, H. J., L. L. Phillips, and W. Rosner. 1972. Separation of subunits of antihemophilic factor (AHF) by agarose gel chromatography. Thromb. Diath. Haemorrh. 27: 212219.

14. Owen, W. G., and R. H. Wagner. 1972. Antihemophilic factor: separation of an active fragment following dissociation by salts or detergents. Thromb. Diath. Haemorrh. 27: 502-515.

15. Rick, M. E., and L. W. Hoyer, 1973. Immunologic studies of antihemophilic factor (AHF, factor VIII). V. Immunologic properties of AHF subunits produced by salt dissociation. Blood. 42: 737-747.

16. Cooper, H. A., T. R. Griggs, and R. H. Wagner. 1973. Factor VIII recombination after dissociation by $\mathrm{CaCl}_{2}$. Proc. Natl. Acad. Sci. U. S. A. 70: 2326-2329.

17. Griggs, T. R., H. A. Cooper, W. P. Webster, R.H. Wagner, and K. M. Brinkhous. 1973. Plasma aggregating factor (bovine) for human platelets: a marker for study of antihemophilic and von Willebrand factors. Proc. Natl. Acad. Sci. U. S. A. 70: 2814-2818.

18. Weiss, H. J., and L. W. Hoyer. 1973. Von Willebrand factor: dissociation from antihemophilic factor procoagulant activity. Science (Wash. D. C.). 182: 1149-1151.

19. Cooper, H. A., and R. H. Wagner. 1974. The defect in hemophilic and von Willebrand's disease plasmas studied by a recombination technique. J. Clin. Invest. 54: $1093-$ 1099.

20. Sarji, K. E., R. D. Stratton, R. H. Wagner, and K. M. Brinkhous. 1974. Nature of von Willebrand factor: a new assay and a specific inhibitor.Proc. Natl. Acad.Sci.U.S.A. 71: $2937-2941$.

21. Sussman, I. I., and H. J. Weiss. 1976. Spontaneous aggregation of low molecular weight factor VIII and its prevention by $2 \mathrm{mM} \mathrm{CaCl}_{2}$. Thromb. Res. 9: 267-276.

22. McKee, P. A., J. C. Andersen, and M. E. Switzer. 1975. Molecular structural studies of human factor VIII. Ann. N. Y. Acad. Sci. 240: 8-33.

23. Switzer, M. E., and P. A. McKee. 1976. Studies on human antihemophilic factor: Evidence for a covalently linked subunit structure. J. Clin. Invest. 57: 925-937.

24. Walsh, K. A. 1970. Trypsinogens and trypsins of various species. Methods Enzymol. 19: 41-63.

25. Blomback, M., B. Blomback, P. Olsson, and L. Svendsen. 1974. The assay of antithrombin using a synthetic chromogenic substrate for thrombin. Thromb. Res. 5: 621-632.

26. Newman, J., A. J. Johnson, M. H. Karpatkin, and S. Puszkin. 1971. Methods for the production of clinically effective intermediate- and high-purity factor-VIII concentrates. Br. J. Haematol. 21: 1-20.

27. Baughman, D. J., D. F. Waugh, and C. Juvkam-Wold. 1968. Properties of thrombin and fibrinogen. Thromb. Diath. Haemorrh. 20: 477-496.

28. Weber, K., and M. Osborn. 1969. The reliability of molecular weight determinations by dodecyl sulfate-polyacrylamide gel electrophoresis. J. Biol. Chem. 244: 4406-4412.

29. Weiss, H. J. 1965. A study of the cation- and pHdependence of factors V and VIII in plasma. Thromb. Diath. Haemorrh. 14: 32-51.

30. Cooper, H. A., F. F. Reisner, M. Hall, and R. H. Wagner. 1975. Effects of thrombin treatment on preparations of factor VIII and the $\mathrm{Ca}^{2+}$-dissociated small active fragment. J. Clin. Invest. 56: 751-760.

31. Switzer, M. E., and P. A. McKee. Factor VIII: one molecule with two activities. Semin. Thromb. Hemostasis. In press.

32. Beck, E. A., P. Bachmann, P. Barbier, and M. Furlan. 1976. Importance of protease inhibition in studies on purified factor VIII (antihemophilic factor). Thromb. Haemostasis. 35: 186-190.

33. Poon, M-C., and O. D. Ratnoff. 1976. Evidence that functional subunits of antihemophilic factor (factor VIII) are linked by noncovalent bonds. Blood. 48: 87-94.

34. Rick, M. E., and L. W. Hoyer. 1975. Molecular weight of human factor VIII procoagulant activity. Thromb. Res. 7: 909-916. 